\title{
V. On some Deposits of Late Tertiary Age at Matura, on the East Coast of 'Trinidad.
}

By R. J. Lechnere Guppy, Esq., Civil Service, Trinidad.

\$1. TNTRODUCTION.-In the Map appended to the 'Report on the Geology of 'Trinidad,' * we find the principal Tertiary coal-bearing strata of the Island indicated by a more or less irregular band of dark colour, stretching from Chaguanas, Couva, and Savonetta, on the western or Parian coast, to Manzanilla on the eastern or Atlantic side. To the north of this band lies a sterile region of detrital matter, chiefly siliceous, marked in the map by yellow with red spots. I wish to draw attention more particularly to that part of this latter formation which lies on the eastern coast between the River Matura and Saline Bay.

On approaching Matura from Valencia, after having crossed the Oropouche River, an evident change for the better is observable in the nature of the soil ; for, instead of the intensely sterile quartzose sand and white clays which form the principal part of the 'stratified detritus,' we find that a portion of calcareous matter has mingled with the earth, and rendered it a little more suitable for agriculture. This calcareous matter seems to have been derived from underlying beds, which might probably be classified as belonging to the ' upper part of the Newer Parian' of the Government Geologists. These beds are in part composed of a dark-coloured and fine-grained calcareous sandstone, containing an abundance of śmall shells. No great extent of these beds is exposed; but near the Rincon, a natural savanna bordering on Matura Bay, the erosion caused by a small stream, and the wasting action of the sea, have brought into view a fossiliferous bed, the organic remains from which may probably give us an insight into the question of its age, and may even lead to a knowledge of some of the physical phenomena which succeeded the deposition of the earlier Tertiaries of the Island.

\$ 2. Organic Remains.-The fossils found by me in the beds alluded to amount to more than ninety species, and have relationships with the recent fauna, with the fauna of the "Post-pliocene" deposits of the Antilles (Barbados, \&c.), and with that of other Tertiaries in this Island. As respects the two former cases, I have been able, for the most part, to compare specimens; but in regard to the Newer Parian fossils, I have not been able to obtain such full information as is desirable. The indications furnished in the Appendix to the Geological Report $\uparrow$ are very meagre; and, after a lengthened, but nevertheless somewhat unsatisfactory, examination of the Matura fossils, I have drawn up the following list.

* Memoirs of the Geological Survey: Report on the Geology of Trinidad; or Part I. of the West Indian Survey; by G. P. Wall, from the Gorernment School of Mines, Jermyn Street, and J. G. Sawkins, F.G.S. 8vo. 1860. London: Longman and $\mathrm{Co}$.

+ Report on the Geology of Trinidad pp. 161-166. 


\section{List of Fossils from the Rincon, Matura, Trinidad.}

(vN., very numerous; s., numerous ; R., rare.)

† Fusus, R.'

* Nurex, R. Pyrula canaliculata, Lam.

$\dagger$ P., sp. Nassa incrassata (?), Müll. Buccinum clausiliforme (?), Kien.

* Terebra succincta, Gmel., R.

* Columbella, sp.

+ C., sp., R. Fossarus costatus (?), Brocchi, r.

* Oliva oryza, Lam., vN.

- Conus venulosus, Brug. Pleurotoma sinuosa, Mont.

* P. fusca (?), Gray. P. virgo (?), Lam. P. nodifera (?), Lam.

$\dagger$ P., sp. Daphnella sicula, Reeve.

* Volvaria catenata(?), Mont., sp., N.

* Persicula, sp.

* Marginella carulescens, Lam.

+ M., sp.

* Erato, sp.

* Natica straminea, Rechu.

$\dagger$ Odostomia, sp., R.

$\dagger$ Chemnitzia, sp.

* Eulima polita, Lin.

* Cerithiopsis, sp.

* C. subulata, Mont.

Triforis ventricosus, Gmel.

Leiostraca acuta, Sov.

* Scalaria pyramidalis, Sow.

* Turritella imbricata, Lin.

† T., sp.

* Cæecum pulchellum.

Vermetus royanus, d'Orb.

* V. lumbricalis, Lin., $\mathrm{N}$.

* Siphonium decussatum, Gmel. Trochus granulatus (?), Born. † T., sp., R.

* Sigaretus Delessertii, Chenu, R.

$\dagger$ Adeorbis, sp., R.

+ A., sp., R.

$\dagger$ A. (?), sp., R.

* Fissurella pileola, Dil.

* Crepidula aculeata, Lam.

Calyptræa (? Crucibulum) albida (?), Crucibulum striatum, $S a y, \mathrm{~N}$.

C. tubiferum, Sovo., N.

* Dentalium apicinum, Lam., N.
* D. entale, Lin.

Chiton, sp., R.

* Tornatina olivula, N.

* Bulla striata, Brug.

* Physa ancillaria, Say, R.

* Planorbis, sp., R.

Ostrea cucullata, Born.

O. cucullata (?), var. terebratuliformis, $\mathbf{R}$.

Pecten nucleus (?), Born.

* Modiola sulcata, Lam.

* Arca Nox, Lin., N.

* A. solida, Sow., N.

* A. donaciformis, Reeve.

* A., sp.

+ A., sp.

* Pectunculus decussatus, Chemn. Nucula similis (?), Sow.

$\dagger$ N., sp., $\mathbf{R}$.

* Leda eburnea (?), Sow.

* Chama macrophylla, Chemn.

* Cardium isocardium, Lin.

$\dagger$ C. (Papyridea), sp., V.N.

C. obovale, Sozv., N.

* Lucina squamosa, Lam.

† Diplodonta (?), sp.

* Strigilla carnaria, Lin. sp., N.

- Astarte (Gouldia) Martinicensis, d Orb., v.s.

* Venus pectorina, Lam., $\mathrm{N}$.

* Venus cingenda, $D i l$.

* V. macrodon, Desh.

$\dagger$ Cytherea, sp., R.

* Trigona mactroides, Chemn.

+ Tapes, sp., $\mathbf{R}$.

* Mactra turgida, Gmel.

+ M. (?), sp., R.

Donax fabagella, Lam.

* D. striata, Lin.

* Tellina acuta, Wood, R.

* Corbula pygmrea, Hanley, v.N.

* C. bicarinata, Sonv., v.N. C. pisum (?), Sow.

* Gastrochæna ovata, Sow.

* Pholadidea calva, Gray.

† Lunulites, sp., v.N.

Cellaria salicornia, Pallas, n.

$\dagger$ ? Discopora, sp.

? Eschara, sp.

In addition to the fossil Mollusca and Bryozoa enumerated in the foregoing list, there are a few small bones, probably of Fishes, and a VOI. II. - NO. XII. 
single tooth has come to light. There are also remains of Cirripedes (Balani), and fragments of Crustacea (brachyurous decapods); also a few spines and fragments of Echinoderms.

The Shells marked* in the preceding list are known to me, by recent examples, to be still existing in neighbouring seas. Those marked $\dagger$ are species otherwise unknown to me, either by books or specimens. Ostrea cucullata is, I believe, a shell of the eastern seas. Cardium (Papyridea), sp., is allied to the recent C. (Papyridea) ringiculum, but is much smaller and thicker.

It will be observed that there are 27 species known as existing in contiguous waters, out of a total number of 56 Gasteropods, including two freshwater shells and two opisthobranchs. Then 16 of the remainder, if not found in the surrounding seas, are probably existing elsewhere. To two of these $I$ have assigned the names Nassa incrassata and Trochus granulatus, on account of their resemblance to the European species of those names, but at the same time with much hesitation.

The proportion of recent species thus arrived at is nearly 80 per cent.; or 20 per cent. of unknown and extinct species. Making due allowance, however, for imperfect knowledge, there would probably remain at least 10 per cent. of extinct species of Gasteropoda.

With regard to the Conchifera, the proportions are nearly the same. There are 22 species, out of the total of 36 , which are certainly known to me to exist in contiguous seas. To this number may be added four species, some of which probably exist elsewhere. Nucula similis and Corbula pisum are species of the European Eocene. I can detect no difference between the examples from Matura and the English species; but some doubt, of course, rests on the determination, owing to the distance both of locality and of time. I think, from what has been stated, that we may consider it moderately safe to infer, that of the fossil Mollusca of the Matura deposit there is a percentage of at least 10 extinct species. This would bring the deposit within the Pliocene Period according to the classification of Lyell ; * and, in searching for European equivalents, we should probably find that the Glacial deposits of Europe present the closest analogies with the Matura beds.

I may remark, by the way, that the fact has not practically been overlooked by Geologists, that even where all the species are recent, yet, if some of them are only found in distant seas, and exist under different climatal conditions to what those occurring in the localities where such species are found fossil lived under, the differences between the recent and fossil faunæ mark a real progress in geological time, and entitle the strata from which the fossils are obtained to a distinctive name. The Matura deposits are, however, less remarkable in this respect than in regard to the small size of the Shells found in them; a point which will be dwelt upon in the following sections of this paper.

$\$ 3$. Conditions of Deposit.-It is probable, from the sandy nature

* Lyell, Manual of Elementary Geology, 5th ed., p. 105, and Supplement, p. 13. 
of the beds, that they were not thrown down at any very great distance from land; while it could hardly have been as a beach that the deposit was accumulated. The Shells are many of them too fragile to have withstood the attrition which accompanies exposure on a beach. We must look, therefore, for a condition intermediate between the two as probably the nearest to the truth; and we find that the fauna is one which would, in most respects, suit a depth of from 20 to 50 fathoms.

On those tropical beaches where Univalves predominate, we have Litorina, Patella, and Nerita. None of these are represented in the Matura beds. On the other hand, on those long stretches of sandy beach in the tropics where the molluscan fauna is chiefly bivalve, we find Mactra turgida, M. carinata, Trigona mactroides, Donax denticulata, D. striata, and, more rarely, Venus granulata, Cytherea dione, and a few Tellens. In the deposits at Matura we have, however, Shells characteristic of a certain depth of water, such as Terebra, Oliva, Marginella, Conus, Erato, Chemnitzia, Eulima, Odostomia, Cacum, Dentalium, \&c., and several of the Conchifera. The only strictly littoral Gasteropod in this collection -namely, Chiton-is represented by a solitary plate. As to the two freshwater species, each of which is represented by a single example, they may have been borne out, on floating wood or otherwise, from some stream of the neighbouring land.

The comparative numbers of the individuals of each species found in the fossil and recent conditions is another matter which deserves some consideration, though I cannot make many complete and accurate observations on that head. 'The little Rice-shell, Oliva oryza, seems to have been almost as common during the deposition of the Matura beds as at present; while the Astarte (Gouldia) Martinicensis is much more rare now than it appears to have been formerly. This small shell occurs in immense numbers in the Matura deposit. Corbula pygmaa is not quite so numerously represented; it is by no means rare in some localities at the present day, but it is second only to the Astarte before mentioned, in point of numbers, in the Matura deposit.

$\S 4$. Climate of the Period of Deposition.-Bearing in mind what has been said respecting the proportion of recent and extinct species, it will appear that these deposits probably belong to an epoch not far removed from that of the Glacial and Preglacial beds of Europe. But the extremely small size of the fossils found at Matura is one of the most remarkable features of the deposit. Even where the Shells belong to recent types of average size, the fossil representatives are almost invariably dwarfed. 'There are only one or two exceptions to this rule; e.g., Cardium isocardium, Turritella imbricata, and Bulla striata, which attain an ordinary, but not a large, growth.

Where the fossil Shells belong to recent types of small size and Arctic genera, they are not smaller than their living representatives. As examples of this, I may cite Astarte (Gouldia) Martinicensis, the Corbula, the Leda, and the Nucula. 
I have been led, by a consideration of the above facts, to enquire whether the refirigeration caused by the extension of glacial action southwards during the Newer Pliocene Period may not have affected lands situated so far south and so near the equator as Trinidad. And it must be confessed, considering the general aspect of the organic remains from the Matura beds, their small size, and the probable contemporaneity of the period of their deposition with the Glacial Epoch in Europe and North America, that there is some likelihood that glacial influences had a share in the modification of this fauna. The influence of climate seems to show itself in the numerical preponderance of individuals belonging to species of Arctic or Northern types, and in the diminutive size generally of the Shells, rather than in the presence of Arctic species.

$\S 5$. Relations with other Trinidad Deposits.-Several of the species found in the Matura beds are identical with those occurring in the Tamana series; and there are also specific affinities with the other 'Tertiaries of the Island, as mentioned in $\$ 2$. But it does not seem, from the lists* given by the Geological Survey, that there is anywhere, as far as has been discovered, the same assemblage of species. The number of recent forms in the beds under consideration forbids us, however, to assign an older date than the 'upper part of the Newer Parian' to them: and, further, the shells from the deposits described in the Geological Report do not possess that general feature of diminutiveness which is so remarkable in the Matura fossils. The Ark found so abundantly in most of the Tertiary deposits of this Island (Arca incongrua of the Geological Survey) seems to be absent from the Matura beds. Further researches will be required to show how far some of the species of Arctic types now existing in the West Indian seas may have commenced their existence in the tropics, from the date of the supposed glacial influences.

There is a ferruginous conglomerate at Saline Bay, some little distance north of the exposed part of the Matura deposits, which may possibly belong to the same period as the latter; but it seems to be unfossiliferous.

$\S 6$. Concluding Remarks.- The facts relative to the Matura deposits may be of great interest and importance, when our knowledge shall have been far enough advanced to enable us to pronounce with some degree of certainty on the physical changes of this part of South America in late geological epochs. There is a great deal to be done in this respect. Before any set of conclusions can be established firmly, the observations on which they have been founded must be confirmed by prolonged investigation. There is, however, an interest of its own attaching to the explorations of our Later Tertiaries; and with regard to the Matura deposit, I may quote the very apposite remark of Mr. James Smith, of Jordanhill,-_'As it belongs to one of the first steps in the descending series, every circum-

* Report on the Geology of Trinidad, pp. 163-6. 
stance connected with it should be carefully observed and recorded, that researches into the more ancient formations may be conducted with greater success:'* and, in addition, it is probable that important inferences with respect to the climate of the earth in former epochs may flow from comparisons such as those attempted in the present paper.

I shall conclude with a few remarks in connection with the possibility of a colder climate having prevailed in the West Indies during the Newer Pliocene period. It is known that species of Cryptogamic Plants found in the Arctic regions lave been discovered on mountains in the torrid zone. Plants indigenous to Lapland have been observed on the Peak of Teneriffe, and on the Blue Mountains in Jamaica. Similar facts have been noticed relative to the Andes. $\dagger$ It remains to be seen how far these phenomena are attributable to the former prevalence of colder climates over large portions of the earth's surface. It is possible that the plants referred to may have first appeared within the tropics during a period when the climate was colder than at present; and that when the conditions of temperature became altered, these plants receded from the lowlands, ultimately occupying only the higher summits of the mountains. There is, however, nothing to show that the climate of the torrid zone was ever such that ice could have been present in quantity.

The idea of those alterations in the climate of the earth which are admitted on all hauds to have taken place having been widely spread, is not now brought forward for the first time, and hypotheses in explanation have been suggested by various observers. 'There may even have been more than one period of comparative coldness, and the phenomena may have recurred according to definite and fixed laws. Again, the climates of the globe might have been such, that while the southern hemisphere was enjoying more than an average share of warmth, the climate of the northern portions of the globe was in a corresponding degree colder; and vice versâ. But to do more than merely to allude to what has been brought forward on these subjects, is beyond the scope of a paper like the present.

In the above paper I have confined myself to a very few remarks on those species of the Mollusca from the Matura beds which are probably new. I have done so, because I do not yet feel justified in publishing new specific names. There are no means of reference, either to Museums or to published works, in this island. Our Public Library scarcely possesses any but the most elementary works on Natural Science. $\oint$ It is, however, but fair to state that the Governors of the Colony have not always been indifferent to the claims of science; and it may be hoped that the time is not far distant when some efforts will be made for the institution of a local Museum and Scientific Library.

Pont of Spain, Trinidad: August 1864.

\footnotetext{
* Smith, Post-Tertiary Geology, p. 5.

† Humboldt, Travels (Bohn's ed. 1852), vol. i. p. 115.

$\ddagger$ Page, Past and Present Life of the Globe, p. 190.

$\S$ See Crüger in Geological Report on Trinidad, p. 176.
} 